\title{
Uloga medicinske sestre u prepoznavanju znakova zlostavljanja osoba starije dobi The role of nurses in recognizing the abuse of elderly people
}

\author{
Sonja Šare', Marija Ljubičic ${ }^{2}$ \\ 'Medicinska škola Ante Kuzmanića Zadar, Franje Tuđmana 24G, 23000 Zadar, Hrvatska \\ 'Medical School Ante Kuzmanića Zadar, Franje Tuđmana 24G, 23000 Zadar, Croatia \\ 2Opća bolnica Zadar, Bože Peričića 5, 23000 Zadar, Hrvatska \\ ${ }^{2}$ General Hospital Zadar, Bože Peričića 5, 23000 Zadar, Croatia
}

\begin{abstract}
Sažetak
Porast udjela starijeg stanovništva doprinio je povećanom prepoznavanju potreba i problema osoba starije životne dobi. lako se posljednjih desetljeća naglašava važnost kvalitete života, zlostavljanje i zanemarivanje tih osoba predstavlja značajan i ne tako rijedak javnozdravstveni i psihosocijalni problem.

Nasilje nad osobama starije dobi nerijetko se događa u obitelji, institucijama i strukturalno u okvirima društvenog okruženja. Razlikujemo fizičko, psihičko, materijalno, seksualno zlostavljanje i zanemarivanje. Samozanemarivanje je također javnozdravstveni problem, ali ne uključuje oblik nasilja, jer se ne odnosi na zlouporabu moći okoline. Posljedice zlostavljanja i zanemarivanja obuhvaćaju oštećenje fizičkog i mentalnog zdravlja, materijalnu nesigurnost, ozljede i smrt.

Djelujući u različitim okruženjima medicinska sestra/ tehničar [MS/MT] imaju mogućnost prepoznavanja simptoma i znakova zlostavljanja i zanemarivanja. Zbog uloge koju ima u skrbi za osobe starije dobi njezino sudjelovanje u primarnoj, sekundarnoj i tercijarnoj prevenciji tog problema od iznimne je važnosti.

Ključne riječi: zlostavljanje • starije osobe • medicinska sestra

Kratki naslov: Zlostavljanje starijih osoba
\end{abstract}

\begin{abstract}
The increase share of the elderly population has contributed to an higher recognition of the needs and the problems of elderly people. Although in the recent decades the importance of the quality of life has been emphasized, the abuse and the neglect of these persons are significant and not so rare public health and psychosocial problem.

Violence against elderly people often happens in families, institutions and structurally within the social environment. We can differentiate physical, psychological, material and sexual abuse and neglect. Self-neglect is also a public health issue, but it does not include a form of violence, because it is not related to the abuse of power of the environment. The consequences of the abuse and the neglect include damage to physical and mental health, financial insecurity, injuries and death.

By operating in different environments the nurse/medical technician (MS/MT) has the possibility to recognize symptoms and signs of abuse and neglect. Due to the role they have in the care of elderly people, their participation in primary, secondary and tertiary prevention of this problem is of utmost importance.
\end{abstract}

Key words: abuse • the elderly • nurse

Runing head: Elder abuse

Received June $17^{\text {th }}$ 2016;

Accepted December $11^{\text {th }}$ 2016;

Autor za korespondenciju/Corresponding author: Sonja Šare, Medical School Ante Kuzmanića Zadar, Franje Tuđtmana 24G, 23000 Zadar, Croatia• Tel: +385 $098478218 \cdot$ E-mail: sonja.sare@ gmail.com

\section{Uvod/Introduction}

Povećanje udjela osoba starije životne dobi u društvu posljedica je porasta očekivanog trajanja života. Takav trend, uz smanjeni natalitet, ima za posljedicu inverzijski odnos u korist starije populacije u odnosu na osobe mlađe životne dobi [1].

Važnost starenja i prava koja imaju osobe starije životne dobi prepoznata su tek prije nekoliko desetljeća. Problemi nastali kao posljedica starenja pučanstva predstavljeni su od strane Ujedinjenih naroda na Svjetskoj skupštini o starenju 1982. godine kada je usvojen Međunarodni plan akcija o starenju. Na Drugom svjetskom skupu o starenju 2002. godine usvojen je Internacionalni akcijski plan o starenju koji sadrži ciljeve i preporuke prevencije zlostavljanja, zanemarivanja i nasilja nad osobama starije životne dobi. Prava osoba starije životne dobi utemeljena su na načelima iz 1991. godine i sadrže nezavisnost, uključivanje, njegu, samozadovoljstvo i dostojanstvo.

Osobe starije životne dobi su posebno osjetljiva i specifična skupina koja je u porastu i često se nailazi na prepreke u otkrivanju problema proizišlih iz narušavanja njihovih prava. Problemi osoba starije životne dobi, poput zlostavljanja i zanemarivanja, proizlaze iz teških obiteljskih situacija koje su nastale zbog društvenih, političkih, socijalnih i materijalnih promjena [2]. U početnim razmatranjima te problematike definiranje zlostavljanja bilo je neujednačeno te se tumačilo kao maltretiranje i zanemarivanje.

Prvi se put definicija zlostavljanja osoba starije životne dobi spominje 1975. godine [2]. Međutim, značajniji interes za tu problematiku javlja se tek krajem osamdesetih i početkom devedesetih godina XX. stoljeća [2]. 
Pojmovno određenje zlostavljanja vrlo je široko i kompleksno. Pojam „zlostavljanja osoba starije životne dobi” označuje pojedinačan ili ponavljajući čin ili nedostatak odgovarajućeg postupanja, koje se događa u bilo kojem odnosu očekivanja i povjerenja, a koje uzrokuje štetu, bol, nepriliku i/ili nevolju u starijoj dobi" [1]. Definiranje nasilja ovisi o socijalnoekonomskoj i kulturnoj određenosti društva.

\section{Teorijski modeli zlostavljanja osoba starije dobi / Theoretical models of the abuse of elderly people}

Teorija je promišljeno i uopćeno znanje o nekoj pojavi ili o više pojava zasnovano na bitnim zakonitostima, principima i metodama [3]. Starenje je prirodan proces s ireverzibilnim i involucijskim procesima u kojem su izražene kvalitativne i kvantitativne promjene u organizmu starijeg čovjeka i kao takav predstavlja složen pojavu koja je pod utjecajem bioloških, socijalnih i psiholoških čimbenika.

Teorijski modeli zlostavljanja osoba starije životne dobi utemeljeni su na psihologiji, sociologiji zlostavljanja djece i nasilja u obitelji zbog njihove ranije prepoznatljivosti. Situacijski model opisuje preopterećenost i nedostatak podrške članova obitelji ili njegovatelja osoba starije životne dobi koji podliježu stresu što za posljedicu ima zlostavljanje [4]. Teorija društvene razmjene opisuje odnos koristi i nagrada između dvoje ljudi koji su najčešće članovi obitelji. Navedena teorija proizlazi iz ovisnosti osoba starije životne dobi o skrbniku. Interakcijska teorija opisuje ponašanje odrasle osobe u ulozi zlostavljača kojoj to predstavlja naučeni obrazac ponašanja iz djetinjstva. Međutim skrbnici koji su bili zlostavljani u mlađoj dobi ne moraju nužno postati zlostavljači što ovisi i o opterećenju stresom. Ekološki model zlostavljanja osoba starije životne dobi opisuje utjecaj okoline te naglašava odnos individualnih i kontekstualnih faktora. Model ističe osobine ličnosti u kontekstu obitelji i socijalno-kulturalnim osobinama zajednice. Feministička teorija temelji se na odnosu i ravnoteži snaga spolova zlostavljača. Političko-ekonomski model ističe marginalizaciju osoba starije životne dobi u društvu koja dovodi do sukoba i nasilja [4].

\section{Vrste zlostavljanja osoba starije dobi / The forms of elder abuse}

Zlostavljanje osoba starije životne dobi može se događati u privatnosti doma, institucijama i strukturalno. Međutim, nasilje se može razvrstati i prema načinu na koji ga zlostavljači provode, pa razlikujemo psihičko, fizičko, materijalno i seksualno zlostavljanje i zanemarivanje[1].

Dok je zlostavljanje prilično zastupljeno u literaturi, podaci o zanemarivanju daleko su manje opisani [5]. Zanemarivanje predstavlja namjerno ili nenamjerno nepružanje osnovnih uvjeta za život i potrebnu njegu. Sastoji se od uskraćivanja ljubavi i poštovanja, namjernog odbijanja brige, hrane i lijekova te predstavlja aktivno zanemarivanje. Ako skrbnici ne ispunjavaju svoju ulogu prema osobama starije životne dobi zbog neznanja ili neupućenosti u potrebe žrtve - riječ je o pasivnom zanemarivanju.

\section{Rizični faktori zlostavljanja i zanemarivanja osoba starije dobi / Risk factors for elder abuse and neglect}

Faktori rizika za zlostavljanje i zanemarivanje osoba starije životne dobi postoje kodžrtve, počinitelja i zajednice. Faktori rizika kodi žrtve jesu: starija životna dob, ženski spol, niže obrazovanje, smanjena mogućnost brige o sebi, slabe ekonomske prilike, deficit mentalnog i tjelesnog zdravlja. Smanjena mogućnost brige o sebi i demencija još uvijek nisu u potpunosti prihvaćeni faktori rizika kod žrtve [1]. Faktori su rizika kod počinitelja: skrbnici ili njegovatelji koji nemaju iskustva ili im je njegovanje nametnuto kao i njegovatelji koji imaju velika očekivanja od starijih osoba, njegovatelji koji nemaju podršku, nezaposleni, njegovatelji koji u anamnezi imaju podatke o anksioznosti, depresiji, povijest zlouporabe alkohola i droga kao i povijest zlostavljanja i zanemarivanja u obitelji [6]. Faktore rizika za zlostavljanje i zanemarivanje nije uvijek moguće točno odrediti kao što ni njihova prisutnost ne znači pojavu zlostavljanja. U istraživanju faktora rizika Campbell i Brownee navode da konzumacija alkohola i povijest zlostavljanja u djetinjstvu povećava mogućnost fizičkog zlostavljanja. Osobe koje su doživjele iskustvo zlostavljanja često pate od depresije, dok osobe koje su zanemarivane imaju problema s tjeskobom [6]. Faktori rizika kod zajednice posljedica su ageizma, diskriminacije i segregacije prema osobama starije životne dobi. Društvo u kojem mladi nisu u mogućnosti ostvariti svoja radna prava razvijaju mitove i predrasude prema osobama starije životne dobi [1].

\section{Uloga medicinske sestre u prepoznavanju znakova zlostavljanja osoba starije dobi / The role of the nurse in recognizing the abuse of elderly people}

Medicinska sestra/medicinski tehničar [MS/MT] član je multidisciplinarnog tima u skrbi za osobe starije životne dobi. Međutim, edukacija MS-a/MT-a iz područja primarne, sekundarne i tercijarne prevencije zlostavljanja i zanemarivanja još uvijek je nedostatna.

MS/MT skrbi za osobe starije životne dobi u privatnosti njihovog doma, institucijama za dnevni ili trajni smještaj i u bolnicama te je u mogućnosti prepoznati znakove zlostavljanja. Medicinska sestra prikuplja podatke koji će omogućiti prepoznavanje medicinskog, psihičkog i socijalnog problema kako bi otvorila put njihovom bržem rješavanju.

Osim općih podataka koji uključuju dob, spol, zanimanje, obrazovanje, bračno stanje kao i povezanost s doktorom obiteljske medicine, prikupljaju se podaci važni za socijalnu anamnezu. Podaci o tome živi li osoba starije životne dobi sama ili u obitelji, te koliki je broj članova obitelji i njihova struktura, zdravstveno stanje, zaposlenost, poteškoće i problemi vezani uz financijsku i ekonomsku strukturu, povezanost sa širim članovima obitelji i prijateljima kao i posjete koje prima, značajni su za procjenu faktora rizika od zlostavljanja. Svako odstupanje od obrasca funkcioniranja zdrave obitelji, koju opisuje V. Satir u svom interaktivnom modelu poštovanja obrazaca ponašanja, razlog su za dalj- 
nju analizu [7]. U obiteljskoj i medicinskoj anamnezi važni su podaci o prisutnosti ovisnosti, psihičkih oboljenja, izloženosti stresu, čestim hospitalizacijama i ozljedama. Procjena obuhvaća podatke o sadašnjem zdravstvenom stanju osobe starije životne dobi, kako se osjeća zadnjih godinu dana, posjećuje li češće ili rjeđe doktora obiteljske medicine i koji su razlozi posjeta [7].

MS/MT, prepoznavajući promjene u životu osoba starije dobi treba poticati na otvorenu komunikaciju radi spoznaje poštuju li se članovi obitelji međusobno, pružaju li si podršku, štite li jedni druge od negativne okoline, imaju li sposobnost kontrole nad sobom i događajima u životu. Procjena izgleda, stanja i ponašanja osoba starije dobi od posebne je važnosti za detekciju problema zlostavljanja i zanemarivanja. Izbor odjeće, frizura, način odijevanja, održavanje osobne higijene, stanje uhranjenosti, način eliminacije, mogućnost održavanja kućanstva i uređenje sredine u kojoj živi pokazatelji su kvalitete života.

Osobe starije dobi najčešće negiraju postojanje zlostavljanja i zanemarivanja zbog srama ili stoga što su zlostavljači članovi obitelji te MS/MT koristi u praksi dokazane modele zdravstvene njege, iako bazično ne opisuju probleme zlostavljanja. Hildergad Peplau je model interpersonalnih odnosa usmjerila prema potrebama osobama oboljelih od mentalnih bolesti, međutim njegova primjena usmjerena je na probleme šire zajednice. Model omogućuje MS-u/MT-u preuzimanje određenih uloga za indentificiranje problema. U susretu s osobama starije dobi medicinska sestra preuzima uloge stranca, izvora informacija, učiteljice, savjetnice vođe i surogata. Kod prvog susreta i faze orijentacije s osobom starije dobi sestra izgrađuje povjerenje kako bi mogla ispitati potrebe i prepoznati problem.

MS/ MT promatra osobu starije dobi sustavno i cjelovito. Promatranje uključuje spremnost na suradnju i način na koji odgovara na pitanja, izgled i držanje tijela, njegovanje vlasišta, stanje sluznica usne šupljine, znakove dehidracije i moguće ozljede nastale hranjenjem, korištenje propisanih naočala ili ispravnog slušnog aparata. Kod osoba starije dobi koje otežano hodaju procjenjuje se imaju li adekvatna pomagala i njihovo sigurno korištenje. Ako je osoba starije dobi primorana boraviti u krevetu ili joj je ograničeno kretanje po kući, utvrđuju se stvarni razlozi te je li joj dopušteno primati posjete i sudjelovati u donošenju obiteljskih odluka. Promatranje uključuje i odjeću: odgovara li ta odjeća godišnjem dobu i je li cjelovita. Ukoliko odjeća prekriva cijelo tijelo provjerava se stanje kože i mogućih ozljeda. Podatci važni za detekciju mogućeg problema jesu i prehrambene navike, broj obroka, tekućinu koju uzima (alkohol), koliko se dnevno odmara i kako noću spava. Važni su znakovi fizičkog zlostavljanja ozljede, hematomi, ogrebotine, opekline, česti prijelomi, znakovi gušenja i pokušaji ubojstva.

Nadalje MS/MT procjenjuje odnos članova obitelji prema osobi starije dobi, ima li prijetnji, kažnjavanja, ignoriranja razgovora i nametanja pitanja smrti što upućuje na psihičko zlostavljanje. E. Duvall, opisujući obiteljski model ističe važnost održavanja izvora pomoći što uključuje financije, društveno prihvatljivo ponašanje i održavanje morala kako bi se razvio osjećaj obiteljskog zajedništva i potpore [7]. Ukoliko se imovinom osoba starije dobi raspolaže bez nji- hove dozvole, posuđuje novac, otvara pošta, potpisuju dokumenti ili mijenja oporuka, identificira se materijalno zlostavljanje.

Kod osoba starije dobi koje žive same u kućanstvu MS-ovi/ MT-ovi nerijetko primjećuju povlačenje u sebe, glavobolju, anksiozne i fobične reakcije. Ako se uz navedene simptome zamijete i poteškoće i bolovi pri mokrenja te ozljede spolovila može se posumnjati na seksualno zlostavljanje. MS/MT fazom provedbe potiče osobu starije dobi na donošenje odluke u kojem prepoznaje problem i postaje nezavisna u ostvarenju svojih prava, što je otežano u slučaju zlostavljanja zbog negiranja, srama i povlačenja u sebe.

Negiranje i nepriznavanje zlostavljanja često je temeljeno na iskrivljenoj percepciji u kojoj osoba starije dobi osjeća kako je svojim ponašanjem zaslužila da bude žrtva zlostavljanja, a nerijetko želi zaštititi zlostavljača [8].

H. Peplau navodi da MS/MT treba osigurati stalnu potporu osobi starije životne dobi i njezinoj obitelji. Krize kroz koje prolazi obitelj u kojoj se zlostavljanje događa, Donna Aquuilera i Janice Mesick svrstavaju u krize situacije navodeći kako su važni faktori ravnoteže kao što je realna percepcija stvarnosti, situacijska podrška i mehanizmi potpore za njihovo rješavanje [7]. MS/MT u svom radu primjenjuju i teoriju socijalne podrške zbog narušavanja psihofizičke ravnoteže tijekom zlostavljanja i zanemarivanja čija je svrha pružanje pomoći kako bi se ublažile ili smanjile negativne posljedice zbog izostanka iste [9]. Izostane li socijalna podrška osobe starije dobi nemaju dovoljno ljubavi, pažnje, prijateljstva, ohrabrenja i potpore. Navedeno može izostati zbog neznanja njihovih članova obitelji, neupućenosti u potrebe ili nezainteresiranosti, o čemu govori pasivno i aktivno zanemarivanje. Podrška je apstraktan pojam koji uključuje psihičku, emocionalnu, i duhovnu komponentu. Posebna su stanja koja zahtijevaju podršku tjeskoba, strahovi, tuga, kognitivne poteškoće, zabrinutost i obiteljski nesporazumi [9].

MS/MT osigurava razumijevanje, znanje, stručnost, topao pristup, sigurnost i dovoljno vremena u radu sa zlostavljanim i zanemarenim osobama starije dobi sa svrhom očuvanja dostojanstva. Ljudsko dostojanstvo izvire iz cjelokupne kvalitete osobe i izvan je njegove moći bez obzira na okolnosti u kojima živi [10]. U pružanju skrbi za očuvanje dostojanstva, važno je između zlostavljane osobe starije dobi i članova obitelji uspostaviti suradnju koja donosi odnos samopoštovanja, prava i odgovornosti. Kod zlostavljanih i zanemarenih osoba starije dobi dostojanstvo se izražava kroz govor, oblačenje, okoliš u kojem boravi, dok njegov gubitak dovodi do degradacije, dehumanosti i gubitka kontrole [10].

U prepoznavanju problema zlostavljanja i zanemarivanja potrebno je razlikovati znakove koji upućuju na samozanemarivanje. Nemogućnost osoba starije dobi da se brinu o sebi zbog narušenog zdravlja, depresije, kognitivnih smetnji i gubitka fizičke snage u kratkom vremenu naziva se samozanemarivanje[11]. M. Gordon opisuje samozanemarivanje kao neuspjeh da se aktivnosti svakodnevnog života obave na društveno prihvatljiv način [12].

MS/MT rade u različitim okruženjima s osobama starije dobi, uključujući i njihove obitelji i zajednicu, surađuje s liječ- 
nicima obiteljske medicine, zdravstvenim djelatnicima u institucijama i socijalnim radnicima te se kritički pozicioniraaju u pružanju kreativnih i inovativnih rješenja koje doprinose promjenama u kvaliteti života osoba starije dobi [13]. Formalna edukacija iz područja prepoznavanja zlostavljanja i zanemarivanja u Republici Hrvatskoj za MS-ove/ MT-ove u potpunosti je neprepoznata. Također, smjernice za postupanje u slučaju prepoznavanja nisu dostupne MSovima/MT-ovima. White opisuje protokole koje koriste MSovi/MT-ovi u Sjedinjenim Američkim Državama u detekciji problema kao i edukacije iz područja sestrinske forenzike. Forenzičke medicinske sestre imaju ključnu ulogu u premošćivanju jaza između prava i medicine te daju znatan doprinos prepoznavanju znakova nasilja [14].

Zadaća je MS-a/MT-a potaknuti osobe starije dobi na aktivno, suodgovorno uključivanje u samozbrinjavanje i prepoznavanje znakova zlostavljanja i zanemarivanja. Programi primarne prevencije zlostavljanja osoba starije dobi uključuju edukaciju zdravstvenih djelatnika te njihovo učinkovito djelovanje u radu s osobama starije dobi. Programi sekundarne prevencije zlostavljanja uključuju djelovanje šire zajednice i pomoć obitelji u krizi. Obitelj je važan čimbenik tjelesne, emocionalne i socijalne potpore za stjecanje znanja, formiranja stavova i ponašanja. Međutim, obitelj može biti i izvor nastanka poremećaja [15]. Tercijarna prevencija ima za cilj pružanje psihosocijalne pomoći osobi starije dobi kao i počinitelju zlostavljanja.

Pred MS-om/MT-om zahtjevan je izazov stjecanja znanja o izvorima i posljedicama nasilja nad osobama starije dobi. Nove edukacije omogućit će pružanje konkretne pomoći obiteljima koje skrbe za svoje osobe starije dobi kao i razvijanje odnosa povjerenja u kojem će žrtve govoriti o zlostavljanju. Konačan je cilj senzibilizacija javnosti na probleme osoba starije dobi kao i smanjivanje njihove marginalizacije i viktimizacije [16].

\section{Zaključak/Conclusion}

Porast osoba starije dobi u svijetu prati i pojavu problema koji proizlaze iz narušavanja njihovih prava koja uključuju nezavisnost, uključivanje, njegu, osobno zadovoljstvo i dostojanstvo. Nasilje nad osobama starije dobi koje se javlja zadnjih desetljeća predstavlja osobni i društveni problem. Prevencija zlostavljanja uključuje multidisciplinarni pristup koji zahtjeva istraživanje, edukaciju stručnjaka i osoba starije dobi kao i senzibilizaciju šire društvene zajednice. MS /
MT treba učinkovito djelovati pred sve većim zahtjevima i potrebama zajednice. Prepoznavanje problema zlostavljanja i zanemarivanja osoba starije dobi nije dovoljno zastupljeno u edukaciji MS-a/MT-a, te se sestre koriste poznatim teorijama i modelima. U rješavanju problema nasilja očekuje se ključna uloga MS-a/MT-a u kreiranju mjera socijalne, zdravstvene i pravne skrbi koja će doprinijeti kvaliteti života osoba starije dobi.

\section{Authors declare no conflict of interest}

\section{Literatura/References}

[1] Rusac S. Zlostavljanje i zanemarivanje starijih osoba u obitelji u: Četiri stupnja gerijatrijske zdravstvene njege sa sestrinskom dokumentacijom i postupnikom opće/obiteljske medicine u domu za starije osobe, Referentni centar Ministarstva zdravlja RH za zaštitu zdravlja starijih osoba, Zagreb, 2012, 322-336

[2] Rusac S, Čizmin A. Nasilje nad starijim osobama u ustanovama. Med Jad 2011;41:51-58.

[3] Ljubičić M, Šare S. Povezanost teorije i prakse u zdravstvenoj njezi. Sestrinski glasnik 2015;20:254-6.

[4] Perel-Levin S. Discussing Screening for Elder Abuse at Primary Health Care level. Geneva: World Health Organisation, 2008.

[5] Vinterstein TB. Nurses Experiences of the Encounter With Elder Neglect. Journal of Nursing Scholarship 2012;55-62.

[6] Campbell AM, Brownee KD. Risk factor characteristic in carers who physically abuse or neglect their elderly depadants. Agong \& Mental Health; 5(1):56-62.

[7] Mojsović Z. Sestrinstvo u zajednici. Zagreb: Zdravstveno veleučilište Zagreb, 2006.

[8] Smith MK, Davis BH, Blowers A, Shena D, Jackson K, Kalaw K. Twelve Important Minutes: Introducing Echanced Online Materials About ElderAbuse to Nursing Assistants. The Journal of Continuing Education in Nursing 2010; 41(6):281-288.

[9] Lopar M, Marendić I, Plužarić J, Rade Z. Teorija socijalne podrške. Teorijska promišljanaj o/u zdravstvenoj njezi. Zbornik studentskih radova. Sveučilište Josipa Jurja Strossmayera u Osijeku. Osijek 2012.

[10] Čebohin M, Grdić LJ, Laurović B, Rimac Sladić D. Teorija samotranscedencije. Koncept dostojanstva. Teorijska promišljanja o/u zdravstvenoj njezi. Zbornik studentskih radova. Sveučilište Josipa Jurja Strossmayera u Osijeku. Osijek 2012.

[11] Dyer CB, Goodwin J, Pickens-Pace S, Burnett J, Kelly A. Self -Neglect Among the Eldery: A Model Based on More Than 500 Patients Seen by a Geriatric Medicine Team. American Journal of Public Health 2007; 97: 1677-1675.

[12] Gordon M. Manual of Nursing Diagnosis: Ontario:Jones and Bartlett publishers 2011.

[13] Vodeća uloga medicinske sestre u inovativnim pristupima zdravstvenoj njezi. HUMS.2008

[14] White SW. Elder Abuse: Critical care nurse role in detection. Crit Care Nurs Q 2000; 23(2) 20-25.

[15] Maćešik B, Špehar B. Prevencija kardiovaskularnih bolesti u primarnoj zdravstvenoj zaštiti. Sestrinski glasnik 2011;19: 30-41.

[16] Ajduković M, Rusac S, Ogresta J. Izloženost starijih osoba nasilju u obitelji. Revija socijalne politike 2008; 1: 3-22. 